\title{
Influence Of Teaching Styles On Students' Achievement And Interest Among Biology Students In Secondary Schools In Taraba State Nigeria
}

\author{
Christina Tanko Audu
}

\begin{abstract}
The study investigated the influence of teaching styles on students' achievement and interest in Biology in Secondary schools in Taraba state. The study was guided by two research questions and two hypotheses. The study adopted the survey and quasi experimental designs. A sample of 336 senior secondary two students from ten secondary schools was drawn using stratified sampling technique. The instrument used for data collection were the Biology Achievement Test (BAT) and Biology Interest Inventory developed by the researcher. Biology teachers in the selected schools were observed and their teaching styles were identified either as students centred or teacher centred using teaching style check list. The treatment was carried out in six weeks during which data were also collected at various intervals using the BAT and BII. The data collected were analyzed using mean and standard deviations to answer the two research questions while analysis of covariance (ANCOVA) was used in testing the two hypotheses at 0.05 level of significance. The findings indicated that there was a significant difference in the mean achievement scores of students' taught Biology using student centred teaching styles and those taught using the teacher centred teaching styles with those taught using student centred teaching styles achieving higher. Also students who were taught Biology using student centred teaching styles had a higher interest rating than those taught using the teacher centred teaching styles. It was recommended that Biology teachers should use student centred teaching styles which provides students the opportunity to take charge of their learning and be actively involve thereby enhancing their achievement and interest and that ministry of Education should organize workshops/seminars to train in-service Biology teachers on how to use student centred teaching styles
\end{abstract}

\section{INTRODUCTION}

The outcry of several science educators and the general public concerning the persistent low achievement of students in the sciences cannot be overemphasized. This under achievement becomes eminent when one considers the performance of students in public examinations. Over the years, various reports have brought to lime light the fluctuating under achievement of students in Biology in the West African Examination Council (WAEC) examinations conducted in Nigeria. This poor trend is particularly evident in the performance of biology students who over the years (2010-2015), have never recorded an average of 50\% credit pass in the examination. Available information from the WAEC (2011) further reveal that biology has the highest students enrolment relative to other science subjects, it however records a very poor performance in senior school certificate examinations (Okoli, 2006).

The persistent under achievement in biology therefore needs to be addressed urgently by employing appropriate techniques in teaching among several other strategies. Determining the influence of teaching styles on students' achievement and interest in biology and could be a step to address this issue of underachievement. The teaching styles used in delivering biology lessons should be selected carefully to enhance better achievement and stimulate the interest of the students. The selection of an appropriate teaching style or approach is important to the 
success of the teaching process (Howard, 2009). Howard further maintained that, to be successful, teachers must learn how to use a variety of teaching strategies by employing appropriate teaching styles that also suit the students learning styles. This is in agreement with Danmole and Femi-Adeoye (2004) where they opined that no single method is best for the teaching of biology. The authors agreed that, teaching styles that would permit students' active participation such as field work, laboratory work (practical activities), group work, concept mapping and inquiry methods should always be used. These methods are most likely to ensure higher performance and promote students' interest in biology.

The term teaching style has been defined by McCoy (2006) as a set of teaching tactics employ by the teacher to help students acquire knowledge or skills. Dupin-Bryant (2004) defined teaching style as "instructional format". In teacher training, teachers may be exposed to more formal learning designs, pedagogical scenarios, lesson planning methodology etc. Teachers then have personality and beliefs are exposit to pre-service and in-service training. The combination of these (training, personality and beliefs) with experience (i.e. concrete exposure to classroom context and policies) will then lead to a given teaching style. A teacher's teaching style is based on their educational philosophy, their classroom's demographic, what subject area they teach and the school's mission statement. According to Grasha (2002) teaching styles define, guide and direct instructional practices that impact students and their ability to learn.

Broadly, teaching style are categorized into teacher centred and students centred. The main focus behind the teacher-centred style is the idea that the teacher is the main authority figure. The students are simply there to learn through lectures and direct instruction, and the focus is mainly on passing tests and assessments. A teachers' role in this style is to pass on the knowledge and information needed to their students. Amad and Aziz (2009) posit that, teacher-centred teaching is the traditional teaching method where teachers are at the centre of class activities. In traditional or teacher centred classrooms, students have definite and fixed perceptions and ideas of their own roles and those of their teachers. Based on these characteristics some teacher centred teaching styles include: direct instruction, formal authority, expert and personal model.

In student centred teaching style, the teacher is still the authority figure, but the student plays an active role in what is learned. The idea is that the teacher will advise and guide the students down a learning path. Assessment involves informal and formal methods tests, group projects, portfolios, and class participation. The teacher continues to assess a student's learning even throughout the lesson. The students are learning the information the teacher is giving, and the teacher is learning how best to approach his students. Eken (2000) stated that in studentcentred classrooms, the teacher serves as a facilitator and students are seen as being able to assume active roles and participate throughout the lesson. These activities the author stated are most likely to promote students' interest in the task especially when the activities are specially fashioned to suit the interest of the students. Teachers facilitate student's discussion and activities and interject only when and where necessary. This gives the students a guided learning environment and helps students to discover facts by themselves (Eken, 2000). When students are allowed to lead discussions and activities, their achievement level is facilitated and their interest towards the subject and task is promoted (Ahmad \& Aziz, 2009). Student centred teaching styles include facilitator, delegator, collaborator, cooperative and personal teaching style.

Ngonga (2002) observed that secondary school students continue to perform poorly due to poor teaching styles as majority of teachers are still over-dependent on teacher-centered styles. To Young and Collin (2003) traditional or conventional teaching style have failed to 
bring about the desired outcome of producing sound and creative students. Howard (2009) asserted that, students who are taught creatively, analytically and practically perform better than students who are taught merely orally or by just telling. Quinonex (2014) confirms that a teacher's teaching style is based on his/her educational philosophy, the school's mission and vision statements. Understanding the diverse contexts of how teachers teach and the corresponding ways in which students learn has penetrated the field of education for some time, yet further studies that would likely unveil some salient facts are encouraged (Pollucks, 2009).

Rennie, Dieking and Falk (2013) were emphatic that, students' active participation in the learning process will enhance achievement since participation encourages and provides students with the opportunities to utilize the knowledge of science in different situations and not just at examination. Sarvey and Duffy (2003) as cited in Odoh (2013) posit that, a science teacher needs to teach students how to learn and not just to give the students what to be learnt. The advent of the paradigm shift from teacher to learner centeredness as examined by Igboko and Ibeneme (2006) was targeted at enhancing students' achievement. Similarly, other approaches such as cooperative instructional strategy, problem-based learning and creating knowledge inquiry strategy were teaching methods and styles meant to engage student participation in the learning process and to arouse their interest in science.

Many students who develop dislike for particular subjects have their reasons for doing so (Achor \& Orji, 2009). They continued that, it could be that they were put off after a lesson, a week, a month or even the entire subject. Some of these students if not all eventually drop the subject along the way. This is to say that, teachers need to adopt teaching styles and techniques that will attract and not repel the students. The teacher-student rapport in the class, use of words, the manner of presentation of the lesson and above all, the display of the knowledge of subject matter could have influence to make the student like or dislike the subject.

Achor and Orji (2009) reported that interest as used in psychological and educational measurement is a motivational construct. It therefore follows that interest in an event is aroused as a result of effort to satisfy a felt need. The individuals need arouses interest and motivates one to take action or to participate in activities that would lead to the satisfaction of that need. Substantiating this view, Njoku (2002) adds that interest is congruent with motivation and both constructs are action based or oriented and directly or indirectly are connected to teaching styles. Schneider (2004), Damole and Adeoye (2004) were of the common opinion that, teaching strategies, methods and tactics that would permit students active participation in the class be encouraged. When appropriately applied in classroom situations, Galton (2009) was optimistic that teaching styles can improve slow learners' level of achievement and promote their interest in the task at hand. Lassa (2005) noted that, teachers are the main determinant of the quality of education in Nigeria. The provision of this qualitative education cannot be achieved without the application of appropriate teaching styles. Adejoh narrated further that, when the appropriate methodology is applied, the teachers will be able to stimulate and sustain the interest of pupils and students throughout the lesson.

Howard (2009) maintained that matching the teachers' teaching styles with the learning styles of the students suggests that educators and science teachers in particular needs to become aware of how students learn. With this, they may be able to create an environment that is conducive for optimal learning. Todays' teaching styles needs to be different from approaches that have been traditionally used. It is time for the schools to start focusing on the innate abilities that children possess rather than on the traditional education formula that is not 
totally consistent with the developmental learning or cognition (Creswell, 2009). Pintrich and Marx (2011) suggested that, a teacher's teaching style therefore should be such that would harmonize both the external and internal environment of the students to bring out their best sequel to their interest.

Interest in science is very important as it motivates students to learn (Bae, 2007). It is however worrisome that, recent studies show a decline in interest of students especially in science as the children grows (Bae 2007). Bae (2007) pointed out clearly that, it is boring for a student to study science topics and difficult to appreciate it's value without interest. These perceived problems and lack of interest on the part of the student is caused by in-appropriate use of teaching styles by the science teachers (Igboko \& Ibeneme, 2006). Also, Adejoh and Idachaba (2010) stressed that biology teachers need to replace conventional methods of teaching with teaching approaches that are both student and interest centered. Igboko and Ibeneme (2006) opined that, teachers of science and technology should move with time and follow the paradigm shift in educational psychology from teacher to learner centeredness. It is therefore reasonable for teachers to initiate all the basics that students need to achieve using appropriate teaching styles to enhance their achievement and arouse their interest in biology.

\section{Statement of the Problem}

The persistent failure of students in science oriented subjects at external examination bodies such as WAEC and NECO is a threat to the attainment of the educational goals and science education in particular. This failure is a signal of a process problem at the secondary school level. Over the years Samba and Eriba (2012) have revealed the poor performance of students in science subjects in general and biology in particular. In fact, students' over dependence on examination malpractice as an option for success at examinations is worrisome. Besides the West African Examination Council (WAEC), other examination bodies such as NECO, NABTEB and even BSEB are always in the campaign with the government against examination malpractice. Yet, this ugly trend still persists in schools. This is a clear signal that, in spite of the campaigns against the trend and teachers' innovative teaching approaches to enhance students' achievement, not much has been achieved. Teachers' teaching styles therefore still needs to be appraised.

In the field of science and science teaching in particular, it is true that many researches have been carried out on teaching styles and students' achievement, yet not much has been achieved. The limited academic achievement of students in science in spite of innovative teaching strategies has no doubt been a problem. Programmes to improve students' achievement in science often have mixed results hence this study intends to further investigate. The question which poses a problem for this research study therefore is, what is the influence of teaching styles on students' achievement and interest in Biology?

\section{Purpose of the Study}

The purpose of this study is to investigate the influence of teaching styles on students' achievement and interest in Biology in Taraba State. Specifically, the study is aimed at achieving the following objectives.

1. Determine the difference in the mean achievement scores of students taught Biology using students centred teaching styles and those taught using teacher centred teaching styles.

2. To determine the influence of teaching styles on students' interest in Biology

\section{Research Questions}

The following research questions have been raised to guide the study. 
1. What is the difference in the mean achievement scores of students taught Biology using students centred teaching styles and those taught using teacher centred teaching styles?

2. What is the difference in the mean interest rating scores of students taught Biology using students centred teaching styles and those taught using teacher centred teaching styles?

\section{Hypotheses}

The following hypotheses were formulated and tested at 0.05 significance level.

1. There is no significant difference in the mean achievement scores of students taught Biology using students centred teaching styles and those taught using teacher centred teaching styles.

2. There is no significant difference in the mean interest rating scores of students taught Biology using students centred teaching styles and those taught using teacher centred teaching styles.

\section{METHODOLOGY}

The study adopted the survey and quasi experimental designs. Two research questions and two hypotheses guided the study. A sample of 336 senior secondary two students from ten secondary schools was drawn using stratified sampling technique. The instrument used for data collection were the Biology Achievement Test (BAT) and Biology Interest Inventory (BII) developed by the researcher. The instruments were validated by three experts in Biology. The Biology teachers in the selected schools were observed and their teaching styles were identified either as students centred or teacher centred using teaching style check list. The treatment was carried out in six weeks during which data were also collected at various intervals using the BAT and BII. The data collected were analyzed using mean and standard deviations to answer the two research questions while analysis of covariance (ANCOVA) was used in testing the two hypotheses at 0.05 level of significance.

\section{Research Question One}

\section{RESULTS}

What is the difference in the mean achievement scores of students taught Biology using students centred teaching styles and those taught using teacher centred teaching styles? Data to answer this research question are presented in Table 1

Table 1. Mean and Standard Deviation of Students' Achievement Scores Taught Biology using Students Centred and Teacher Centred Teaching Styles

\begin{tabular}{lcccccc}
\hline Groups & $\mathbf{N}$ & $\begin{array}{c}\text { Pretest } \\
\text { Mean }\end{array}$ & SD & $\begin{array}{c}\text { Posttest } \\
\text { mean }\end{array}$ & SD & $\begin{array}{c}\text { Mean } \\
\text { Gain }\end{array}$ \\
\hline $\begin{array}{l}\text { Students Centred Teaching } \\
\begin{array}{l}\text { Style } \\
\text { Teacher Centred Teaching }\end{array}\end{array}$ & 177 & 10.08 & 2.54 & 18.92 & 2.72 & 8.84 \\
$\begin{array}{l}\text { Style } \\
\text { Mean Difference }\end{array}$ & 159 & 10.07 & 1.99 & 16.47 & 2.76 & 6.40 \\
\hline
\end{tabular}

Table 1 shows that in the pre-test the student centred group has a mean of 10.08 and standard deviation of 2.54 and teacher centred group has a mean of 10.07 and standard deviation of 1.99. This shows that the two groups were homogenous to some extent at the beginning of the experiment. The result in Table 1 also shows that the student centred group has a mean of 18.92 while the teacher centred group has a mean of 16.47 in the post-test. The mean gain of the students taught Biology using student centred teaching styles was 8.84 and that of those 
taught using teacher centred styles was 6.40. The overall mean difference between the groups was 2.44 in favour of students taught using student centred teaching styles.

This means that the mean achievement of students taught Biology using students centred teaching styles was higher than those taught using the teacher centred teaching styles. By implication the use of student centred teaching styles enhanced higher achievement of students in Biology more than teacher centred styles.

\section{Research Question Two}

What is the difference in the mean interest rating scores of students taught Biology using students centred teaching styles and those taught using teacher centred teaching styles?

Table 2: Mean and Standard Deviation of Interest Rating Scores of Students taught Biology using Students Centred and Teacher Centred Teaching Styles

\begin{tabular}{lcccccc}
\hline Group & $\mathbf{N}$ & $\begin{array}{c}\text { Pre- BII } \\
\text { Mean }\end{array}$ & SD & $\begin{array}{c}\text { Post- BII } \\
\text { Mean }\end{array}$ & SD & $\begin{array}{c}\text { Mean } \\
\text { gain }\end{array}$ \\
\hline Student centred & 177 & 1.10 & 0.57 & 3.15 & 0.85 & 2.05 \\
Teacher centred & 159 & 1.06 & 0.48 & 2.13 & 0.81 & 0.99 \\
Mean Difference & & & & & & $\mathbf{1 . 0 6}$ \\
\hline
\end{tabular}

Table 2 reveals that students in the student centred teaching style group have a mean interest rating of 1.10 and standard deviation of 0.50 in the pre-BII while those in the teacher centred teaching style have a mean interest rating of 1.14 and standard deviation of 0.48 in the pre-BII. In the post-BII students in the student centred teaching style group have a mean interest rating of 3.15 and standard deviation of 0.85 while those in the teacher centred teaching style have a mean interest rating of 2.13 and standard deviation of 0.81 . The mean difference was 1.06 . Therefore the mean difference in Biology interest scores of students in the student centred teaching style group was higher than that of those in the teacher centred group.

\section{Hypothesis One}

There is no significant difference in the mean achievement scores of students taught Biology using students centred teaching styles and those taught using teacher centred teaching styles.

Data to test hypothesis one are presented in Table 3

Table 3: ANCOVA test on students' achievement in student centred and teacher centred groups.

\begin{tabular}{llcccc}
\hline Source & $\begin{array}{l}\text { Type III Sum of } \\
\text { Squares }\end{array}$ & Df & Mean Square & F & Sig. \\
\hline Corrected Model & $1428.79 a$ & 4 & 357.19 & 48.31 & .00 \\
Intercept & 1525.45 & 1 & 1525.45 & 206.32 & .00 \\
Pretest & 570.02 & 1 & 570.02 & 77.09 & .00 \\
Group & 769.15 & $\mathbf{1}$ & 769.15 & $\mathbf{1 0 4 . 0 2}$ & $\mathbf{. 0 0}$ \\
Error & 2447.34 & 331 & 7.39 & & \\
Total & 83827.00 & 336 & & & \\
Corrected Total & 3876.14 & 335 & & & \\
\hline
\end{tabular}

Results in Table 3 shows that at $\mathrm{F}_{1335}=104.02$, $\mathrm{P}$ - value of 0.00 was less than $0.05(\mathrm{P}<0.05$. $)$. Therefore, the null hypothesis is rejected. The interpretation is that there is a significant 
difference between the mean achievement scores of students taught Biology using students centred teaching styles and those taught using teacher centred teaching styles. This further confirmed the fact that the difference in mean scores between the group taught using student centred teaching styles and those taught using teacher centred teaching style is statistically significant indicating the effectiveness of the use of student centred teaching styles.

\section{Hypothesis Two}

There is no significant difference in the mean interest rating scores of students taught Biology using students centred teaching styles and those taught using teacher centred teaching styles.

Table 4: ANCOVA Test on Mean Interest Rating Scores of Students in Students Centred and Teacher Centred Teaching Styles.

\begin{tabular}{lrcccc}
\hline Source & $\begin{array}{c}\text { Type III Sum of } \\
\text { Squares }\end{array}$ & Df & Mean Square & F & Sig. \\
\hline Corrected Model & $1252.87 \mathrm{a}$ & 4 & 313.21 & 640.91 & .000 \\
Intercept & 276.79 & 1 & 276.79 & 566.38 & .000 \\
Pre-BSTII & 1246.44 & 1 & 1246.44 & 2550.48 & .006 \\
Group & 2.43 & 1 & 2.43 & 4.98 & .016 \\
Error & 867.45 & 331 & 2.62 & & \\
Total & 17493.00 & 336 & & & \\
Corrected Total & 2120.32 & 335 & & & \\
\hline
\end{tabular}

Table 4 reveals that $P$-value $(.016)$ is less than 0.05 at $F_{1}, 1775=4.98$. Therefore, the null hypothesis is rejected. By implication, there is significant difference in the mean interest ratings between students taught Biology using students centred teaching styles and those taught using teacher centred teaching styles with those taught using student centred having higher interest rating scores.

\section{DISCUSSION OF FINDINGS}

The first finding of the study is that students taught Biology using student centred teaching style achieved higher than those taught using teacher centred teaching styles. This finding corroborate that of Lazarides and Ittel (2012) who also found that students who were taught Mathematics using student centred teaching style achieve higher than those taught using teacher centred. The finding also agreed with the result of a study conducted by Pollocks (2009). The reason for the higher achievement by the student centred group could be because the students were actively involved in the learning process which resulted to meaningful learning. This further confirm the assertion by Galton (2009) that students achievement in any field of study can be greatly enhance if students are allow to take charge of their learning. Interaction among the students provides a better opportunity to develop their cognition. As provided by Vygotsky (1924) social constructivism theory that knowledge is the result of social interaction and learning can occur in groups of similarly skilled individuals if they are motivated to help each other. Another reason for the better performance of students taught using students' centred teaching style could be because students are captivated, more focused, attentive and interested in what they are doing. This no doubt offers slow learners an opportunity of catching up which could also enhance their performance.

In terms of interest the finding indicated that students taught Biology using students centred teaching style had higher mean interest rating than students who were taught using teacher centred teaching style. This means that student centred style enhances students' interest in Biology. The result gave credence to what was earlier found by Okigbo and Okeke (2012) that 
students' interest in a subject can be improved through the use of appropriate teaching technique. Student centred teaching styles are expected to be highly stimulating thereby increasing students' interest in the subject but teacher centred style can be cumbersome and tiresome thereby making the learning process difficult and uninteresting. The student centred group must had enjoyed their learning and thus had their interest in Biology increased more than those in the teacher centred group. As earlier pointed out in literature, today's students are growing with and also getting their information via visual tools like television, GSM set, computer and internet etc. Getting their interest by traditional teaching style where a lot of channels compete for their attention is becoming difficult therefore teaching styles which compel the students' attention and cooperation and makes learning a pleasurable experience can be utilized to evoke curiosity, stimulate and sustain students' interest in Biology.

\section{CONCLUSION}

Based on the findings of the study, the researcher arrived at the conclusion that the use of students centred teaching styles enhances students' achievement and interest in Biology more than the teacher centred teaching style.

\section{RECOMMENDATIONS}

Based on the findings of the study, the following recommendations are hereby made:

1. Basic science and technology teachers should use student centred teaching styles which provides students the opportunity to take charge of their learning and be actively involve thereby enhancing their achievement and interest.

2. Ministry of Education should organize workshops/seminars to train in-service Basic Science and Technology teachers on how to use student centred teaching styles.

\section{References}

Achor, E.E. \& Orji, A.C. (2009).Level of students' motivation in classroom interaction in integrated science. Journal of Research in Curriculum and Teaching, 4(1), 294-303.

Adeojoh, M.J. \& Idachaba, J.A. (2010).Challenges in educating children for rapid scientific and technological development in Nigeria. Book of Readings: The Teacher in the Contemporary Nigeria Society, 2(2), 187-202.

Ahmad, F. \& Aziz, J. (2009).Students' perceptions of the teachers' teaching of literature communicating and understanding through the eyes of the audience.European Journal of Social Sciences 7(3) 17-26. Retrieved from http://www.eurojournals.com/ejss.

Bae, M. (2007).Interest in science education.Erdwardsville: Illinois University Press.

Danmole, B.T., \& Femi-Adeoye, K.O. (2004). Effect of concept mapping technique on senior secondary school students' achievement and retention of ecological concepts. Journal of the Science Teacher Association of Nigeria, 39(1\&2), 32-38.

Eken, D.K. (2000). Through the eyes of the learner: learner observation of teaching styles and learning. ELLT Journal, 53(4), 66-80.

Grasha, A, F (2002).Teaching with style: a practical guide to enhancing learning by understanding and Learningstyles. Alhance Publishers.

Howard G. (2009). The impact of teaching styles and other related variables on student achievement in mathematics and implications for curriculum management.An Unpublished Ph.D Thesis Attanta University.

Igoko, K.O. \& Ibeneme, O.T. (2006).Effects of some cognitive constructivist instructional approaches on students' achievement and retention in the study introductory technology in Nigeria.Journal of the Science Teachers Association of Nigeria, 41 (1\&2), 37-43.

Lazarides, R.\&Ittel, A. (2012). Mathematics interest and achievement: What role doperceived parent and teacher support play? A Longitudinal Analysis. Selected Papers Presented at the First Network Gender and STEM Conference, 5(6), 208-231

McCoy, M. R. (2006), Teaching style and the application of adult learning principles by police instructors, Policing: An International Journal of Police Strategies and Management, 29, (1) 77-91 
Ngonga, B. (2002).An assessment of englishlanguage teacher education in the light of classroom needs: A Case Study of Maseno University. An Unpublished P.hD Thesis, Maseno University.

Njoku, Z.C. (2002). Enhancing girls' acquisition of science process skills in co-educational school: An experience with sex grouping for practical chemistry.Journal of the Science Teachers Association of Nigeria, 37 (1\&2), 69-75.

Odoh, C.O. (2013). Effects of cooperative instructional strategy on achievement in Seniorsecondary chemistry. Journal of Research in curriculum and Teaching, 7(1), 583-589.

Ogbeba, J.A. \&Muhuku, A.I. (2013). Influence of two school environmental variables on students' achievement in Biology in Gwagwalada Area Council of FCT-Abuja. Journal of Research in Curriculum and Teaching, 7(1), 575-582.

Okeke, E.A.C. (2007). Making science education accessible to all.23rdInnangural Lecture.University of Nigeria Nsukka.

Pullocks, S.B. (2009). The effects of teaching styles on male achievement in single sex and co-educational classrooms in selected school districts in Georgia. An unpublished P.hD thesis.

Quinonex, N. (2014). Different teaching styles and how they affect students. Buckingham: Open University Press.

Rennie, S., Dieking, P. \& Falk, S. (2013).Level of students participation in senior secondary practical physics.Retrieved from http://www.sc.world.res.ref.

Samba, R.M.O \&Eriba, J.O (Eds) (2012).Innovative approaches in teaching difficult science concepts.Makurdi: Destiny Ventures.

Schneider, G.L. (2004). Do suplemental educational services increase opportunities for minority students? An Appraisal.Phi Delta Kappan, 86(1), 110-115.

Vygotsky, L.S. (1924). Methodology of Reflexological and Psychological Research.Retrieved on 01-09-2014 from http://www.kolar.org/vygotsky.

Young, R. \& Collin, A.A. (2003).Constructivism and Social Constructivism in Career Field.Journal of Vocational Behaviour, 64, 373-388. Retrieved from http://www.etas.edu.au. 